\title{
The choice between bank debt and trade credits in business start-ups
}

Nancy Huygebaert • Linda Van de Gucht • Cynthia Van Hulle

Published online: 26 June 2007

(C) Springer Science+Business Media B.V. 2007

\section{Erratum to: Small Bus Econ}

DOI 10.1007/s11187-006-9005-2

The original version of this article unfortunately contained a typo in the title.

Please note that the correct title should be:

The choice between bank debt and trade credits in business start-ups

The online version of the original article can be found under doi: 10.1007/s11187-006-9005-2

N. Huygebaert $(\bowtie) \cdot$ L. Van de Gucht $\cdot$ C. Van Hulle K.U. Leuven, Naamsestraat 69, Leuven 3000, Belgium e-mail: Nancy.Huyghebaert@econ.kuleuven.be 